\title{
Endobiogeny: A Global Approach to Systems Biology (Part 2 of 2)
}

\author{
Endobiogeny: 一种系统生物学的全球方法（第 2 部分, 共 2 部分) \\ Endobiogenia: un enfoque global de la biología de los sistemas (Parte 2 de 2)
}

Jean-Claude Lapraz, MD, France; Kamyar M. Hedayat, MD, United States; Patrice Pauly, PhD, France

Author Affiliations Société internationale de médecine endobiogénique et de physiolo-

gie intégrative, Paris, France (Drs Lapraz and Pauly); American Society of Endobiogenic Medicine and Integrative physiology, San Diego, California, United States ( $\mathrm{Dr}$ Hedayat).

Correspondence Kamyar Hedayat, MD acquamarine@mac.com.

Citation Global Adv Health Med. 2013;2(2):32-44. DOI: 10.7453/gahmj.2013.013

Key Words Endobiogeny, systems biology, reductionism,

functional medicine

Disclosure

The authors have completed the ICMJE Form

for Disclosure of Potential Conflicts of Interest and disclosed that all have a financia stake in Endobiogenics Inc, Pocatello, Idaho.
Editor's note: The following is the abridged version of part 2 of a two-part article. Part I of the article was published in the January 2013 issue of Global Advances in Health and Medicine. To read the unabridged version of this article, which includes a discussion of direct and indirect indexes, visit www.gahmj.com.

\section{THE BIOMARKERS}

\section{Experimental and Clinical Basis for the Biomarkers} Used in the Biology of Functions

Endobiogeny and the biology of functions are based on four scientific concepts that are known and generally accepted: (I) human physiology is complex and multifactorial and exhibits the properties of a system; (2) the endocrine system manages metabolism, which is the basis of the continuity of life; (3) the metabolic activity managed by the endocrine system results in the output of biomarkers that reflect the functional achievement of specific aspects of metabolism; and (4) when biomarkers are related to each other in ratios, it contextualizes one type of function relative to another to which is it linked anatomically, sequentially, chronologically, biochemically, etc.

As will be shown in this article, the relationship between various hormones and particular biomarkers is a long and well-established fact based on modern physiology and scientific method. The indexes composed from these biomarkers have been derived through inductive reasoning and confirmed by more than 30 years of clinical practice. The indexes have not been individually validated in the peer-reviewed literature. However, it stands to reason that if the correlation of each biomarker to endocrine activity is sufficiently demonstrated, then it is possible that such a biological modeling system may be a more valid assessment of biological activity.

\section{Bone Marrow: Complete Blood Count}

Life is permanent dynamism, and the circulation of blood ensures this dynamism. Blood plasma is a conduit of information, a delivery system of nutrients, and a remover of metabolic waste, but it is the cellular elements - white blood cells (WBCs), red blood cells (RBCs), and platelets - that serve to deliver oxygen and defend, heal, and protect the body. The endocrine system as the manager of metabolism determines the rate of production of cellular elements from the bone marrow. Thus blood is the foundation of life, and the endocrine system as the manager of blood is the manager of this foundation. The evaluation of blood cells reveals how the endocrine system manages life.

\begin{tabular}{|c|c|c|c|}
\hline Origin & Biomarker & Value & Conversion \\
\hline \multirow{9}{*}{$\begin{array}{l}\text { Bone marrow } \\
\text { cellular products }\end{array}$} & Red blood cell & per $\mu \mathrm{L}$ & $\div 10^{6}$ \\
\hline & White blood cell, total & $\operatorname{per} \mu \mathrm{L}$ & $\div 10^{3}$ \\
\hline & Neutrophil & $\%$ & None \\
\hline & Lymphocytes & & \\
\hline & Eosinophils & & \\
\hline & Monocytes & & \\
\hline & Basophils & & \\
\hline & Hemoglobin & $\mathrm{g} / \mathrm{dL}$ & None \\
\hline & Platelets & per $\mu \mathrm{L}$ & $\div 10^{3}$ \\
\hline Bone marrow-serum interaction & Erythrocyte sedimentation rate & $\mathrm{mm} / \mathrm{h}$ & None \\
\hline \multirow[t]{2}{*}{ Bone stroma enzymes } & Osteocalcin & $\mathrm{ng} / \mathrm{mL}$ & Proprietary \\
\hline & Alkaline phosphatase bone isoenzyme & $\%$ & Proprietary \\
\hline \multirow[t]{2}{*}{ General enzymes } & Lactate dehydrogenase & IU/L & Proprietary \\
\hline & Creatine phosphokinase & & \\
\hline Endocrine & Thyroid-stimulating hormone & $\mu \mathrm{IU} / \mathrm{mL}$ & None \\
\hline \multirow[t]{2}{*}{ Electrolytes } & Potassium & $\mathrm{mmol} / \mathrm{L}$ & None \\
\hline & Calcium, total serum & $\mathrm{mmol} / \mathrm{L}$ & $\div 2$ \\
\hline
\end{tabular}


In the biology of functions, more than $60 \%$ of biomarkers used are derived just from the cellular elements of blood, made in the bone marrow (Table I). The complete blood count (CBC), then, is the basis of the biology of functions. Androgens and estrogens stimulate the proliferation of red and white blood cells, respectively. Thus, sex hormones are the foundation of the CBChence of life - and the initial point of study in the biology of functions. (The bone stroma, discussed below, plays three key roles: protection and nourishment the marrow, regulation and assistance in global energy management, and communication of the state of the peripheral terrain to the central nervous system). ${ }^{\mathrm{I}-3}$

The roles of androgens, and then later estrogens, as the basis of life are evident from the time of conception. For the first I7 days, it is the mother's hormones that the embryo shares. At day I 8 of life, the yolk sac becomes the first endogenous source of RBCs. ${ }^{4,5}$ Rich in androgen receptors, the yolk sack stimulates erythropoietin, which itself plays a role in yolk sac maturation of RBCs, 5 establishing the key role of androgens in the foundation of structure. ${ }^{6}$ The liver is an intermediate source of red blood cells, ${ }^{4}$ also under the management of androgens. ${ }^{7}$ By 34 weeks of gestation and throughout the remainder of life, the bone marrow, stimulated by androgens and estrogens, becomes the source of the majority of blood cells. ${ }^{8}$

In summary, the activity of androgens and estrogens is reflected in the output of red and white blood cells by the bone marrow. The evaluation of this activity, called the Genital Ratio, is used in the majority of indexes of the biology of functions. To accept the hypothesis that red blood cells are a biomarker of androgen activity and that total white blood cell count is a biomarker of estrogen activity at the level of the tissues is to accept the foundation of the majority of indexes of the biology of functions.

\section{Red Blood Cells}

Based on studies over the last 50 years, we postulate that RBCs are a biomarker of the functional role of androgens in metabolism. These studies demonstrate that the administration of androgens stimulate erythropoesis, the development of RBCs.9-15 It is our belief that using RBCs as a marker of the functionality of androgens may prove to be more clinically relevant than quantitative measurements for four reasons: contradictory studies regarding serum levels of androgens and clinical effects, the complimentary nature of estrogens, the role of genomic vs non-genomic effects, and genetic variations in intracellular (IC) conversion of androgens.

Limits of Quantitative Measurements of Androgens. Multiple studies have positively associated elevated levels of serum androgens, RBCs, or both in hypertension, ${ }^{\mathrm{I}-\mathrm{I} 9}$ thrombus formation, ${ }^{20-28}$ impaired insulin sensitivity, ${ }^{29,30}$ and insulin resistance. ${ }^{3 \mathrm{I}}$ However, low serum levels of androgens have also been positively associated with the same disorders. ${ }^{22-35}$ For example, while androgens are positively associated with dyslipidemia, they have also been associated with a reduction in triglycerides and LDL. ${ }^{2 \mathrm{I}}$ Thus, evaluating serum androgen levels may be misleading.

Protective Role of Estrogens? For years, it was believed without strong evidence that delayed cardiovascular mortality in women was due to a protective effect of estrogens. Prospective studies of estrogen supplementation demonstrated not only that supplemental estrogens offered no benefit but that they elevated the risk of cardiovascular events. ${ }^{36-38}$ The lack of definitive protective effects of estrogens and the harmful effects of elevated and low serum levels of androgens in some men and not others suggests to us that it is the relative ratio of androgens to estrogens that is clinically relevant, not the absolute quantitative value of either in isolation.

Are Androgens Harmful in and of Themselves? Studies suggest that androgens alone are not predictive of life span or risk of death from cardiovascular disease in men ${ }^{39-4 I}$ or women. ${ }^{42-45}$ Rather, androgens appear to be but one of many factors in a complex interplay of endocrine drivers of metabolism that influence the development, progression, and severity of a wide range of disorders from vascular disease ${ }^{\mathrm{I} 6,46}$ to Alzheimer's disease. ${ }^{47}$ This may be one reason that assessments relying on serum androgens measurements alone have been inconsistent or contradictory.

Determining Androgen Function: Genomic and Non-genomic Effects. Androgens, like most other steroidal hormones, have genomic and non-genomic effects..$^{48}$ The ability to evaluate the relative impact of non-genomic vs genomic affects in a particular individual may help solve the conundrum of whether high or low androgen activity is protective or harmful.

The genomic of effects of androgens are what have been associated with serum levels of androgens. In contrast to the non-genomic effects, these effects take hours to occur and are linked to many of the classic effects associated with androgens deemed to be harmful when dysregulated. These effects include smooth muscle proliferation, migration, and vasorelaxation; increased monocyte migration and foam cell production; and increased apoptosis. ${ }^{48}$

Non-genomic effects occur within seconds. Mechanisms of action are believed to include a novel membrane-bound receptor, second messenger activation, and sex-hormone binding globulin receptors. Many of the non-genomic effects of androgens are physiologically beneficial and explain the protective effects of androgens observed in studies. They include relaxation of smooth muscle, increased neuromuscular signal transmission by calcium regulation, improved neuroplasticity, cellular proliferation and migration, and modulation of the transcriptional effects of classic androgen receptors. ${ }^{49,50}$ What is clinically relevant is that these non-genomic effects cannot be blocked by drugs that block androgen receptor activity. This may explain two observations: (I) the 
variability of responsiveness to androgen blockers and (2) factors of risk and protection from disease cannot be reliably assessed by quantitative measurement of serum androgens, sex hormone binding globulin, or free androgen levels-because their effects do not rely solely on receptor activity.

Determining Androgen Function: Metabolic Pathways. There are a number of other factors adding to the difficulty of equating quantitative levels of testosterone (free or total) with androgen functionality. Recent studies have demonstrated in vitro and in vivo sex-based variability in androgen receptor sensitivity and concentration in various tissues. ${ }^{43}$ Approximately $5 \%$ of testosterone is converted within the cell to either dihydrotestosterone (DHT) or estrogens.

In summary, the individual effects of testosterone on the body can vary based on (I) genomic effects, (2) non-genomic effects, (3) receptor concentration, and (4) IC conversion tendency between DHT and estradiol. The net effect can be an amplification of genomic or nongenomic effects (DHT) or a counter-balancing effect (estrogens). Therefore, we believe that RBCs may be a useful biomarker reflecting the global degree of tissue functionality of androgens when evaluated relative to other factors.

\section{White Blood Cells}

WBCs, also known as leukocytes, are blood elements that mature in the bone marrow then enter the circulation. Leukocytes consist of five types of cells that arise from a common hematopoetic precursor. White cells differentiate into neutrophils, monocytes, eosinophils, basophils, and lymphocytes. Estrogen stimulates a proliferation of leukocytes in the bone marrow. ${ }^{\mathrm{I}}$ Leukocytosis is associated with high estrogen states such as pregnancy ${ }^{52}$ and autoimmunity,, 33 as well as during the acute phase of infections. Thus, we believe that total WBC count can be considered to reflect the basic tissue effect of estrogens throughout the body.

Limits of Quantitative Measurements of Estrogens. The challenges of evaluating the role of estrogens in human physiology are far greater than for androgens, which is why specific aspects of estrogen activity requires more than a single biomarker.

Estrogen activity is complex, varied, and fundamental to human life. It involves endocrine and metabolic functions, both genomic and non-genomic in nature. Of all sex steroids, metabolically estrogens require the greatest number of metabolic conversions, being derived as such: cholesterol $\rightarrow$ progesterone $\rightarrow$ androgens $\rightarrow$ estrogens. Estrogens can be produced in the ovaries, in the adrenals, and by peripheral conversions in various tissues. 54,55 The pattern of estrogen production (central vs peripheral, adrenal vs gonadic vs hepatic) varies based on hereditary factors, age, and parturition status and is affected by endocrine disrupters. $54-57$

There are multiple active forms of estrogens (estrone, estradiol, and estriol) as well as varying degrees of activity of estrogen metabolites. There are two types of estrogen receptors (alpha, beta), which have opposing activity with respect to cellular proliferation and various metabolic function. There are genetic polymorphisms in 4450 metabolism of estrogens and polymorphisms with respect to receptor sensitivity, concentration, and rate of aromatase activity as well as non-genomic effects, which in sum all impact the effects of estrogens..$^{58-64}$ In their review of estrogen metabolism, Zhu and Conney conclude,

\section{Studies that identify genetic and environmental factors influencing estrogen metabolism at or near estrogen receptors in target cells may be of considerable importance since these factors could profoundly modify the biological effects of estro- gens in complex manners depending on the path- ways of metabolism that are affected and the biological activities of the metabolites that are formed. Such effects need not be associated with an altered profile of estrogen metabolites in the blood or urine. ${ }^{6 \mathrm{I}}$}

Estrogens: Beneficial or Harmful? As with androgens, clinical trials are conflicting with respect to the beneficial or harmful role of estrogens in the body. The protective role of estrogens in cardiovascular disease has come under question, as we have discussed above. ${ }^{36-38,54}$ With respect to cancer, estrogens can promote or lower the risk for cancer in and of themselves and in conjunction with other hormones. ${ }^{65-68}$ The contradictory nature of estrogen's effects on telomere length and the role of telomere length in cancer serve as other good examples of the limitations of both quantitative hormone measurement and single-cause theories of disease. Estrogens increase telomere length. Women have the longest telomere length when follicle-stimulating hormone and estrogen peak during the menstrual cycle. ${ }^{69}$ Telomere length is positively correlated with the rate of apoptosis and inversely associated with the risk of cancer. However, estrogens also cause leukocytosis, which is associated with shorter telomere length, less apoptosis, and greater risk of cancer ${ }^{69,70}$ Telomere length alone, like quantitative levels of estrogen, does not appear to be a sufficient indicator of the global effects of estrogens on the terrain.

The Case for Multiple Biomarkers of Estrogen. In conclusion, estrogens have various sources of origin, various rates of metabolism, and changing concentrations and receptor densities throughout life and can be affected by and affect other hormones in the body, as well as being disrupted by endocrine disrupters. Mounting evidence suggests that serum and urinary levels of estrogen and their metabolites may not be sensitive or specific enough measures of the effects of estrogens.

We hypothesize, based on experimental evidence and clinical studies, that specific functional effects of estrogens can be inferred through the evaluation of particular serum biomarkers in and of themselves, as well as in conjunction with other biomarkers in increasingly 
complex ratios. In the biology of functions, this assessment of estrogen function is accomplished by evaluating six different biomarkers: (I) total WBC count, (2) percent neutrophil count, (3) percent monocyte count, (4) percent lymphocyte count, (5) thyrotropin-stimulating hormone (TSH), and (6) serum osteocalcin. Of these, WBC count is used as a general marker of global estrogen effects on tissues and is the most foundational. Through the use of the genital ratio or its variation, the corrected genital ratio (see "Indirect Indexes"), WBC count can be used to evaluate the structural, functional, and adaptive role of estrogens in the body.

\section{Neutrophils}

Neutrophils are a type of leukocyte that arise from granulocytes in the bone marrow. While the total leukocyte count (WBC count) reflects global tissue effects of estrogens, we hypothesize that neutrophils can be used to assess particular aspects of estrogen activity, namely immune regulation and anabolism of tissue.

The Direct role of neutrophils is to participate in the immunologic response of the organism to aggressors. This can occur through inflammation ${ }^{71}$ or phagocytosis of microbes and cellular debris. ${ }^{72}$ Neutrophilia, absolute or relative, is associated with the anabolism of tissue, such as during pregnancy, ${ }^{7 \mathrm{I}}$ wound healing, ${ }^{73}$ autoimmune disease, ${ }^{74-76}$ and cancer. ${ }^{77-81}$ Estrogens are associated with these same events: preeclampsia, ${ }^{7 \mathrm{I}}$ autoimmune diseases, ${ }^{82}$ and cancer, ${ }^{60}$ as well as wound healing. ${ }^{83-88}$ The majority of patients suffering from autoimmune disease are women, which implies a role for estrogens in the etiology of these disorders. New-onset autoimmune disease is frequently diagnosed in the peripartum period, and flare-ups of existing disease often occur during pregnancy as estrogen levels increase up to Ioo-fold from nonpregnant levels. ${ }^{89,90}$

Neutrophils ordinarily exhibit a short half-life of 3 to 6 hours, requiring a constant production by bone marrow to maintain normal circulating levels. Estrogens affect neutrophil populations in two ways. They increase the total production of neutrophils in bone marrow, ${ }^{9}$ and they inhibit apoptosis of circulating neutrophils, which increases the relative percentage of neutrophils in the total leukocyte differential, even when the leukocyte count is within normal limits, ie, in noninfectious states..$^{2}$ Estrogens manage the production and maintenance of neutrophils; thus, estrogens manage a particular aspect of immunity related to inflammation, host-defense, autoimmunity, and cancer. Therefore, neutrophils may be considered as a biomarker of the role of estrogens in immunologic, inflammatory, and anabolic activity within the body.

\section{Monocytes}

Monocytes are WBCs derived from monoblasts in the bone marrow. They play an important role in the immune system, combating foreign organisms in the blood through phagocytosis and the release of proinflammatory cytokines. After 24 to 72 hours of circulation, they migrate into extravascular tissue where they differentiate into macrophages or dendritic cells (histocytes).

Typically, monocytes represent $3 \%$ to $8 \%$ of the total leukocyte population. Follicle-stimulating hormone (FSH) stimulates estrogen production and estrogens suppress monocyte production. ${ }^{93}$ During adaptation, as FSH and estrogen levels rise, monocyte levels should fall, indicating an anabolic response commensurate to the initial anti-anabolic activity of cortisol. The lower the monocyte count, the greater the influence of FSH and estrogen on the adaptation response, but this needs to be evaluated relative to the eosinophil count, which reflects the role of adrenocorticotropic hormone (ACTH) on adrenal stimulation, as well as other factors.

Conversely, monocytosis is inversely related to the relative efficiency of FSH in stimulating estrogen production. In menopause, monocytosis is observed. ${ }^{94}$ Monocytosis also reflects a relative or absolute insufficiency of estrogen's activity during adaptation ${ }^{95}$ and is associated with increased risk of mortality in multiple diseases marked by dysregulation of the immune system such as lupus, ${ }^{96}$ autism, ${ }^{97}$ asthma,,${ }^{98}$ sepsis, ${ }^{99}$ atherosclerosis, ${ }^{\text {IOO }}$ myocardial infarction, ${ }^{\text {IOI }}$ myeloprolifer

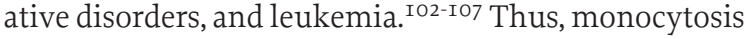
implicates a terrain that is more favorable to inflammation and altered immune states: in other words, a terrain of dysadaptation of estrogen activity.

As the bioavailability of estrogens and androgens are inversely related to each other due to the activity sex hormone binding globulin, ${ }^{108}$ and as monocytosis reflects a relative insufficiency of estrogens during adaptation, monocytosis also reflects a more predominant peripheral androgen activity relative to that of estrogens. ${ }^{\text {Iog }}$

\section{Eosinophils}

Eosinophils are a subpopulation of white blood cells. Fundamentally, the role of the eosinophil is to serve as an indirect method of adaptation and congestion when the adrenal cortical response is not sufficiently adapted to the needs of the organism.

While estrogens, as noted above, have a general effect on the proliferation of all leukocytes within the bone marrow, it is ACTH and cortisol that affect the circulating levels of eosinophils. The degree and intensity of ACTH activity on the adrenal cortex is proportional to the level of circulating eosinophils. Thus, the greater the ACTH solicitation of adrenal activity is, the greater the rise in eosinophils. ${ }^{\text {I IO,I I I }}$ Eosinophilia, relative or absolute, is proportional to the degree of adrenal insufficiency, which is proportional to the demand for ACTH and inversely proportional to the efficiency of cortisol. ${ }^{\text {I }{ }^{2, \text { II } 3}}$

On the other hand, cortisol is inversely related to the eosinophil count because it reduces circulating eosinophils in three ways: (I) suppression of eosinophil maturation, recruitment, and survival ${ }^{\mathrm{II} 4}$; (2) sequestration of mature eosinophils in lymphoid organs $^{\text {II5; }}$ and (3) stimulation of eosinophil apoptosis 
through transcriptional up-regulation. ${ }^{\text {II } 6}$ The greater the degree of circulating cortisol, the lower the eosinophil count. The lower the circulating cortisol activity, the higher the eosinophil count.

While eosinophils cannot replace the complex roles that cortisol plays in the body, they can compensate in part for some of the adaptive functions of cortisol with respect to immune modulation. Eosinophils have direct antimicrobial effects through the production of RNase enzymes ${ }^{\text {II } 7-\mathrm{I} 26}$ and the generation of reactive oxygen species and are immunomodulatory through antigen presentation to T-cells. ${ }^{\text {I27-I33 }}$ Indirectly, they are an indirect source of histamine, which modulates the immune system. ${ }^{\text {I34,I35 }}$

In summary, eosinophil count is used in the biology of functions to assess the intensity of the ACTH solicitation of adrenal activity (positively correlated) and the relative efficiency of cortisol activity (inversely correlated). The less efficient the adaptation response is, the lower the circulating cortisol levels, the greater the role of ACTH in re-stimulating the adrenal cortex, and the higher the circulating eosinophil count will be. Eosinophils also contribute to the evaluation of inflammation, thrombosis, and immune and other activities.

\section{Basophils}

Basophils are the least populous of all white cells. Basophils have been likened to circulating mast cells and play a role in the innate immune response, particularly against allergens ${ }^{\mathrm{I} 36}$ and parasites. ${ }^{\mathrm{I} 37}$ Basophils share similar receptors to eosinophils, such as eotaxin, and may serve as a tertiary method of adapting the adrenal response to aggressors in the face of inadequate cortisol response and insufficient eosinophil response. They are found in high concentration in the circulation and extracellular (EC) spaces of the skin and lungs in patients with atopic disease. ${ }^{1{ }^{8}}$ The percent basophil count on differential is used in only one index in the biology of functions but indirectly in all indexes in which the total WBC count is used.

\section{Lymphocytes}

Lymphocytes are a subset of leukocytes that are the direct mediators of immunity. The lymphocytes count is the sum of all three subsets of lymphocytes: natural killer (NK), T, and B cells. NK cells are part of the innate immune system. They survey and directly attack viruses and tumors. T and B cells comprise the adaptive immune system. $T$ cells manage cell-mediated immunity through the secretion of cytokines and regulate the activity of other immune cells and lyse cells infected by viruses. T cells also play a role in immunoregulation. $\mathrm{B}$ cells form antibodies specific to a unique aggressor and retains a memory of the aggressor in case of future aggression. Lymphocytes play a role in cancer surveillance, immunity, and autoimmunity. The concentration of total circulating lymphocytes can be related to three factors: cortisol, estrogen, and TSH.

Cortisol is inversely related to lymphocyte counts.
It reduces the circulating concentration of all three subtypes of lymphocytes and augments destruction of lymphocytes. ${ }^{\text {I39-I } 42}$

Estrogens are also inversely related to lymphocytes. There are several lines of evidence and clinical observations related to this. Estrogens directly inhibit the proliferation of lymphocytes. ${ }^{\text {I43 }}$ In high-estrogen states, such as pregnancy, there is a relative suppression of lymphocyte proliferation in order to reduce immune attack by the mother against the fetus..$^{2}$ Autoimmune disorders occur disproportionally in females who tend to have higher levels of estrogen activity and estrogen variability. ${ }^{144}$ There is an additional risk of developing autoimmune disease in the peripartum state when there is a terrain of hyperestrogenism and thyroid overstimulation. ${ }^{145,146}$ Estrogens augment the infiltration of lymphocytes into various tissues, reducing the level of circulating lymphocytes. ${ }^{\text {I44 }}$

The relationship between serum TSH and peripheral lymphocytes is positively correlated to the metabolic needs of the body and the degree to which TSH is used to modulate thyroid activity. ${ }^{\mathrm{I} 47, \mathrm{I} 48}$ When the lymphocyte counts are elevated, serum TSH levels tend also to be elevated, and the body tends to be in a state of increased need of thyroid activity. For example, in subclinical hypothyroidism, there is an increased appeal to TSH to stimulate the thyroid. These patients have lymphocyte counts that are elevated relative to euthyroid patients and/or in an absolute sense. When the body's demand for thyroid hormones have been met by exogenous administration of thyroxine, lymphocyte counts reduce from their pre-intervention levels. ${ }^{\mathrm{I} 9}$

In disorders of thyroid overactivity, such as Grave's disease or autoimmunity, there is diminished appeal by the thyroid to TSH for stimulation. One does find diminished peripheral blood lymphocytes in these patients, though not consistently. ${ }^{150}$ As we will demonstrate later in this article, other assessments of thyroid function (see the sections on lactate dehydrogenase and creatine phosphokinase) help further contextualize thyroid efficiency.

In summary, lymphocytes are inversely related to the degree of cortisol and estrogen activity in adaptation and tissue anabolism. The greater the degree of cortisol expression and/or the greater the predominance of estrogen activity, the lower the lymphocyte levels. Lymphocytes are directly related to the degree of appeal to TSH to regulate thyroid function. The higher the lymphocyte count, the greater the appeal to TSH is and often the greater the degree of thyroid insufficiency. Conversely, the lower the lymphocyte count, the more successful TSH has been in modulating thyroid activity regardless of the serum TSH level.

\section{Platelets}

Platelets are circulating blood cells that arise from megakaryocytes in the bone marrow. Platelets have four direct functions in the body: hemostasis, repair and growth of connective tissues, transport of various factors, 
and modulation of inflammation. The hemostatic function of platelets has been observed for more than I2O years and is well characterized. ${ }^{\text {5I }}$ Platelets secrete numerous growth factors for the regeneration of connective tissue once hemostasis has been achieved, including platelet-derived growth factor, insulin-like growth factor I, fibroblast growth factor, and others. ${ }^{152,153}$

In general, platelets are adsorbers of numerous factors in the blood, such as clotting factors and calcium, which allows them to participate in immediate hemostatic activity. ${ }^{154}$ In addition, platelets serve as the direct transporter of serotonin from the enteric cells where they are produced. Serotonin aids in intestinal motility and carbohydrate absorption. ${ }^{\mathrm{I} 5}$ Serotonin also plays constitutive roles in the regulation of bone density. ${ }^{\mathrm{I}} \mathrm{I} 56-\mathrm{I} 58$ Thus, platelets contribute to these physiologic activities as a serotonin transporter.

Platelets participate in proinflammatory activity, adapting innate and adaptive immune mechanisms through the expression of chemokines and cytokines and receptor-receptor interaction with leukocytes. ${ }^{159}$ Platelets also contain histamine, which is secreted before aggregation occurs. ${ }^{160}$

In the biology of functions, after the total WBC and $\mathrm{RBC}$ count, platelets are the most important biomarker derived from the bone marrow. Through the starter index (discussed below), they are used to correct the genital ratio (RBC:WBC) in order to evaluate the role of genital hormones during adaptation. The genital ratio corrected is used in more than $50 \%$ of the indexes of the biology of functions. Platelets, along with other factors, are used to assess histamine activity, risk of thrombosis, thromboembolic phenomena, adrenaline activity, and peripheral serotonin activity.

\section{Hemoglobin}

Hemoglobin ( $\mathrm{Hg})$ is a metalloprotein found within RBCs. Each red blood cell contains four $\mathrm{Hg}$ subunits with an iron molecule in the center of each $\mathrm{Hg}$ subunit. The direct role of $\mathrm{Hg}$ is to bind and deliver oxygen from the lungs to the tissues and bind and deliver carbon dioxide from the tissues back to the lungs. Thus, Hg plays a role in acid-base balance as well as oxygen delivery.

$\mathrm{Hg}$ is an important determinant of the oxygen content of arterial blood, based on the equation of the calculation of arterial oxygen content $\left(\mathrm{C}_{\mathrm{A}}\right)$ :

$\mathrm{C}_{\mathrm{A}}=[\mathrm{Hg}(\mathrm{g} / \mathrm{dL}) \times \mathrm{I} .34 \times$ arterial saturation of blood (percent)] $+[0.0032 \times$ partial pressure of oxygen (torr)]

For a given saturation of blood and rate of consumption of oxygen, the lower the hemoglobin content is, the lower the oxygen content will be. Thus, the more the cardiac output must increase in order to maintain an equivalent rate of oxygen delivery. This can be expressed in the following equation, based on a rearrangement of the Fick equation:

$$
\mathrm{Q}=\left(\mathrm{VO}_{2} /\left(\mathrm{C}_{\mathrm{A}}-\mathrm{C}_{\mathrm{V}}\right)\right) * \mathrm{IOO} \text {, }
$$

where $\mathrm{Q}$ = cardiac output, $\mathrm{VO}_{2}=$ oxygen consumption, $\mathrm{C}_{\mathrm{A}}=$ arterial oxygen content, and $\mathrm{C}_{\mathrm{V}}=$ venous oxygen content.

In vivo and clinical studies demonstrate that in both children and adults, iron-deficiency anemia upregulates alpha-sympathetic activity regardless of the origin of the anemia (genetic, hemorrhagic, renal, acute or chronic) resulting in cardiovascular diseases such as cardiac remodeling and coronary ischemia. ${ }^{161-166}$ Anemia appears to alter the normal adaptive response to stressors, resulting in overadaptation. ${ }^{167}$

Based on these observations, we hypothesize that $\mathrm{Hg}$ can be viewed as a marker of the degree of alphasympathetic activity in adaptation. Because the general adaptation syndrome is initiated by alpha-sympathetic discharge (ie, noradrenaline), $\mathrm{Hg}$ comes to play an important and pervasive role in the biology of functions.

\section{Bone Stroma-derived Enzymes}

Two key stroma-derived enzymes are osteocalcin and alkaline phosphatase bone isoenzyme. In addition to their bone-related activity, they have direct effects on non-bone metabolic activity. These biomarkers in particular and the skeletal system in general inform the central nervous system of the state of the internal milieu, helping it modulate basal and adaptive capacities to meet the needs of the organism. ${ }^{-1}-3$

Osteocalcin. Osteocalcin is a noncollagenous protein. Within the skeletal metabolism, it plays an important role in osteoblasty, fixing ionized calcium to hydroxyapatite crystals. In its nonskeletal role, osteocalcin plays a key role in global energy regulation and adaptation in at least three ways:

I. Glucose regulation: It improves the production and secretion of and cellular sensitivity to insulin, as well as the rate of glucose metabolism. 2,3,168-170

2. Fat regulation: It increases the metabolism of adipocytes. ${ }^{2,3,170}$

3. Adenosine triphosphate (ATP) production: It augments the number and efficiency of mitochondria both in part from its role in glucose regulation and independent of this role. ${ }^{2}$

Serum osteocalcin measures the inactive carboxylated form. When osteocalcin is decarboxylated to its active form, it enters the tissues. The less active osteocalcin is, the higher the serum levels. The more active a role it plays in global metabolism, the lower the serum level.

Osteocalcin regulates and is subject to regulation by various anabolic hormones. Serum osteocalcin is inversely related to insulin-like growth factors $(\mathrm{IGFs})^{\mathrm{I} 7 \mathrm{I}}$ and estrogen activity. Estrogens stimulate osteoblasts to fix calcium, which requires active, carboxylated osteocalcin, which results in a decrease in serum decarboxylated osteocalcin. ${ }^{\text {.72-174 }}$ TSH levels vary inversely with serum osteocalcin levels. ${ }^{175-177}$ Serum osteocalcin is directly correlated with tumor growth in both hormone independent and hormone-dependent tumors. ${ }^{178, \text { I79 }}$ 
The wide-ranging impact of osteocalcin on the structure (bones) and function (metabolism) of the body cannot be overstated, thus its key role in the biology of functions, where it is involved in over $60 \%$ of the indexes.

Alkaline Phosphatase Bone Isoenzyme (APBi). Alkaline phosphatases are hydrolytic enzymes that work in an alkaline environment. They hydrolyze phosphates to be (re)used in the formation of proteins and nucleotides and in the mineralization of bone. Though present in all tissues, they are concentrated in the liver and bile ducts, bone, intestine, and placenta, for which isoenzymes have been identified. ${ }^{180}$

APBi is present in the plasma membrane of osteoblasts. It is an indicator of bone mineralization ${ }^{\mathrm{I} 8 \mathrm{I}}$ and bone turnover. APBi is influenced by thyrotropic hormones in managing bone density. ${ }^{176} \mathrm{APBi}$ is inversely associated with the efficiency of IGFs, ${ }^{182, I 83}$ but the strength of this association depends on other factors as well. APBi's relationship to IGFs implies a relationship between serum APBi and all the activities in which the IGF family plays a role, such as energy production through regulation of glucose entry into the cell, membrane permeability, free radical production, ATP production, inflammation, etc. APBi is also an indicator of dysregulated growth and is associated with acute lymphocytic leukemia, Paget's disease, and metastasis of cancer to the bone. ${ }^{180}$

\section{Systemic Enzymes}

Creatine Phosphokinase. Creatine phosphokinase (CPK) is an enzyme that manages the ultra-acute energy needs of the body. It manages the homeostatic state between ATP and adenosine diphosphate (ADP) and the reservoir of phosphate between creatine and phosphocreatine. Based on computer modeling paradigms and in vitro experiments, phosphocreatine, not ATP, carries the majority of energy produced by oxidative phosphorylation out of the mitochondria into the cytoplasm. ${ }^{\text {I84 }}$

When the cell has sufficient ATP, it donates a phosphate to creatine, creating phosphocreatine and ADP. Phosphocreatine is a stable reservoir of phosphate. When the cell needs an immediate augmentation of ATP, phosphocreatine donates a phosphate to ADP, which then becomes ATP. During periods of sudden increases in metabolic demand throughout the body ${ }^{185}$ and in tissues with chronically elevated energy requirements, there is increased demand for CPK to transfer phosphate from ADP back to ATP. This allows for instantaneous availability of energy without de novo ATP production. ${ }^{184}$ The enzyme CPK catalyzes both reactions (Figure I).

Skeletal and cardiac muscles contain the greatest concentration of CPK as they have the greatest needs for ultra-acute adaptation of energy. In general, when there is insufficient response to a metabolic demand, cells die, either by apoptosis or necrosis, ${ }^{186}$ resulting in either case in elevated amounts of CPK in the serum. This is classically observed during ${ }^{187}$ and rhabdomyolysis. ${ }^{188}$ Thus, serum CPK is proportional to the rate of muscle turnover and the metabolic role of androgens (which anabolise muscle) but not in a strictly linear way nor as the sole determinant of these functions. ${ }^{\text {I89 }}$

Elevated CPK levels in the serum are also associated with myocardial infarction ${ }^{\mathrm{I} 90}$ but lack sensitivity and specificity as a sole biomarker of acute myocardial infarction. ${ }^{\text {IgI }}$ Biomarkers such as total white count, total neutrophil count, and platelets increase the sensitivity of the diagnosis and risk of mortality, which is consistent with the endobiogenic posit that multiple biomarkers are required to accurately assess complex physiologic events. ${ }^{\text {I } 22,193}$

CPK levels correlate with the degree of ATP flux due to insufficiency of oxidative phosphorylation, ie, mitochondrial strain but again, not in a strictly linear way. As a method of assessing oxidative deficiencies, serum CPK levels alone are neither necessary nor sufficient, but one of many associated factors, ${ }^{186}$ as is evidenced in cases of chronic fatigue syndrome where patients have normal cytochrome enzyme activity. ${ }^{\text {I94 }}$ Subclinical thyroid dysfunction (SCTD) has been associated with elevated morbidity and mortality in diabetes and cardiovascular disease, both of which are disorders of deranged redox states. ${ }^{\text {I95-I97 }}$

CPK is inversely related to thyroid metabolic activity $^{\text {198,I99 }}$ and may be elevated in hypothyroidism and SCTD. CPK has been shown to be inversely related to free $\mathrm{T}_{3}$ and free $\mathrm{T}_{4}$ levels in both the diagnosis and treatment of hypothyroidism. ${ }^{200,201}$ However, in any particular patient, the correlation is not linear, which supports the endobiogenic theory that quantitative expression of thyroid hormones is neither sufficiently precise nor reliable to determine the actual metabolic impact of thyroid hormones on cellular metabolism.

Lactate dehydrogenase. Lactate dehydrogenase

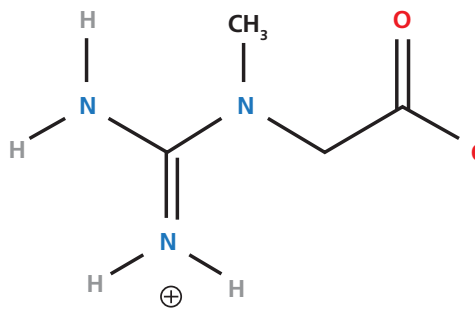

Creatine

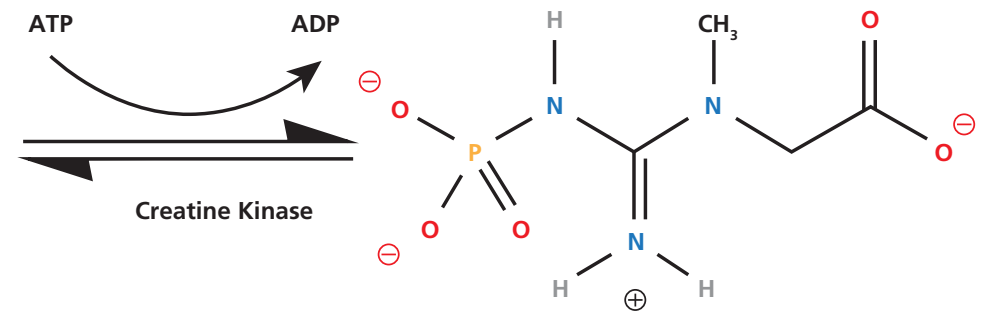

Phosphocreatine

Figure 1 Interconversion of adenosine diphosphate (ADP) and adenosine triphosphate (ATP). 
(LDH) is an enzyme that catalyzes the inter-conversion of pyruvate and lactate (Figure 2). Aerobic respiration, using glucose as a substrate, is the most efficient manner of ATP production in the cells. The preferential pathway in the cell is to metabolize glycogen to glucose to pyruvate. Pyruvate is then converted to acetylCoA, which enters the Krebs cycle. When there is an insufficiency of coenzymes in the Krebs cycle and/or oxidative stress, LDH activity increases in order to convert pyruvate to lactate. Lactate generates ATP by anaerobic metabolism but at a much lower yield than is attained with aerobic metabolism of glucose. $\mathrm{LDH}$ also converts lactate back into pyruvate to produce glycogen as energy storage for future use.

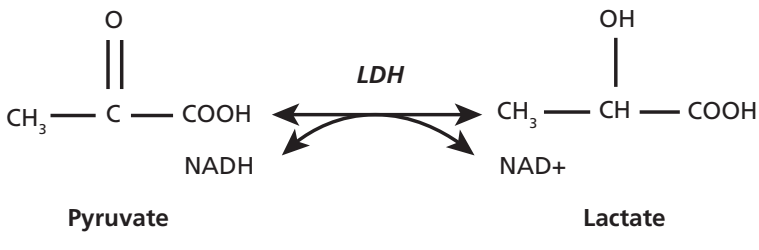

Figure 2 Lactate dehydrogenase (LDH) conversion of pyruvate and lactate.

LDH is contained in large amounts in the liver (the direct storage site of glycogen), as well as cardiac muscle (a major consumer of glucose) and in certain tissues and red blood cells but is found in the serum at low levels. An elevation of $\mathrm{LDH}$ in the serum represents a state of impaired oxidation of glucose relative to demands of the organism, as seen in cardiac ischemia, ${ }^{202,203}$ muscle turnover, ${ }^{186}$ rapid cell and tissue growth, ${ }^{204}$ hemolysis, ${ }^{205,206}$ and cancer. ${ }^{207-209}$

\section{Endocrine}

Thyroid-stimulating hormone. TSH is a glycoprotein created in and secreted from the anterior pituitary gland. In clinical medicine, it is considered strictly within its intrathyroid activity of stimulation of thyroxine ( $\mathrm{T}_{4}$ ) and triidothyronine ( $\left.\mathrm{T}_{3}\right)$, ie, merely as a barometer of thyroid function. Based on more current studies and the endiobiogenic theory of terrain, serum TSH levels have key intra- and extrathyroid implications that should also be considered if the clinical significance of a serum TSH level is to be properly contextualized.

Euthyroidism is defined as normal thyroid function that occurs with normal serum levels of TSH and T4. It has been assumed that TSH and serum levels of $\mathrm{T}_{4}$ have an inverse linear relationship based on classic feedback loops and that this relationship is a reliable indicator of the sufficiency of thyrotropic regulation of metabolism.

There are a sufficient number of anomalies to this assumption that raise questions about its validity. For example, euthyroid sick syndrome is defined as a clinical condition with normal thyroid function with a normal TSH levels but low serum $\mathrm{T}_{4}$ and $\mathrm{T}_{3}$. Subclinical hypothyroidism is a condition in which there is a functional hypothyroid state based on an elevated serum TSH but a normal serum T4. Subclinical hyperthyroidism is a functional hyperthyroid state based on a serum
TSH value below the normal limit but normal $\mathrm{T}_{4}$. Finally, patients with normal serum levels of TSH, T4, and $\mathrm{T}_{3}$ may present with symptoms consistent with hypo- or hyperthyroidism. See the section on creatine phosphokinase for a further discussion of the functional evaluation of thyroid metabolic activity.

More recent studies demonstrate that serum TSH lacks a log-linear relationship to thyroid output of free $\mathrm{T}_{4}$ (fT4) and free $\mathrm{T}_{3}$ (fT3) (Figure 3). In their evaluation of 3223 untreated patients referred for thyroid testing, Hoermann et al found poor correlation $\left(\mathrm{R}_{2}=0.236\right)$ between TSH and fT4. For example, a serum TSH of I.O $\mathrm{mU} / \mathrm{L}$ (0.4-4.I mU/L) was associated with a $\mathrm{fT}_{4}$ anywhere between $4 \mathrm{pmol} / \mathrm{L}$ and $28 \mathrm{pmol} / \mathrm{L}$ (9.5-25 pmol/L). Conversely, a free $\mathrm{T}_{4}$ of $\mathrm{I} 4.5 \mathrm{pmol} / \mathrm{L}$ was associated with TSH between O.I $\mathrm{mU} / \mathrm{L}$ and IoO $\mathrm{mU} / \mathrm{L}^{\mathrm{I}}{ }^{\mathrm{I} 8}$

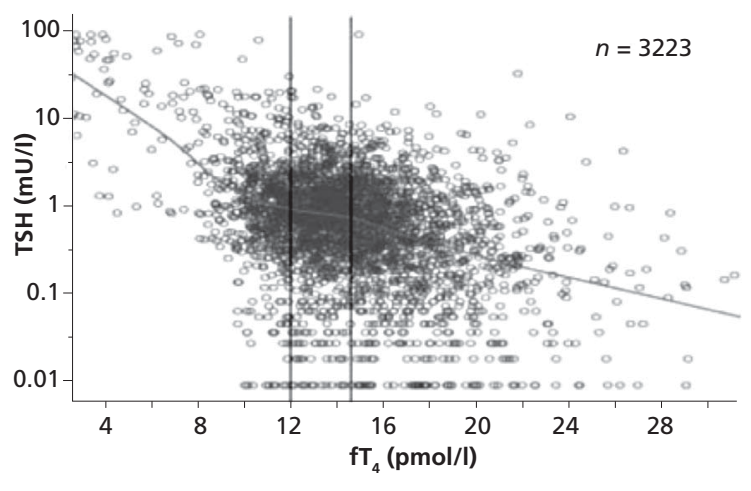

Figure 3 Thyroid-stimulating hormone (TSH) relationship to thyroxine $\left(\mathrm{T}_{4}\right)$.

Regression analysis of $\mathrm{fT}_{4}$ vs log TSH. Fitting data set 1 with the use of SPSS and cut-off values estimated from Figure 1 indicated three distinct regression lines, which were significantly different from each other and described by the following equations: $a\left(\mathrm{fT}_{4}<12\right)$ : $\mathrm{TSH}=-0.13 \times \mathrm{fT}_{4}+1.46 ; \mathrm{b}\left(12 \leq \mathrm{fT}_{4} \geq 15\right)$ : $\mathrm{TSH}=-0.06 \times \mathrm{fT}_{4}+0.05 ; \mathrm{c}\left(\mathrm{fT}_{4}>15\right)$ : $\mathrm{TSH}=-0.07 \times \mathrm{fT}_{4}+0.89 ; \mathrm{a}$ vs $\mathrm{b}: P<.0001 ; b$ vs c: $P=.0002$; and a vs c: $P=.0001$.

From Hoermann R, Eckl W, Hoermann C, Larisch R. Complex relationship between free thyroxine and TSH in the regulation of thyroid function. Eur J Endocrinol. Jun 2010;162(6):1123-1129. Reprinted with permission.

In our opinion, the serum level of TSH only reflects the responsiveness of the thyroid to stimulation without determining the final degree of metabolic efficiency of $\mathrm{T}_{4}$ or $\mathrm{T}_{3}$ or the degree to which thyroid catabolic activity has been adapted to anabolic demands from estrogen.

TSH has a number of extrathyroid relationships and functions independent of $\mathrm{T}_{4}$ or $\mathrm{T}_{3}$. TSH receptors are found in divergent tissues throughout the body. ${ }^{2 \text { IO }}$ $\mathrm{TSH}$ activity is augmented by estrogen. ${ }^{2 \mathrm{I} 2-2 \mathrm{I} 4} \mathrm{TSH}$ is suppressed by somatostatin. ${ }^{2 \text { I I }}$ TSH helps regulated bone density as well. ${ }^{\text {775,I76 }}$

In summary, in the theory of endobiogeny, serum TSH is used to evaluate intra- and extrathyroid activity. Serum TSH is not a sufficient indicator of the efficiency of thyroid regulation of metabolism but can help contextualize thyroid function relative to the demands of the body.

Electrolytes. Potassium and calcium are the only two electrolytes used in the biology of functions. 
Potassium. Potassium is the direct IC ion in the body and serves to maintain the resting membrane potential. IC levels are around I4O $\mathrm{mmol} / \mathrm{L}$ and EC levels, $4 \mathrm{mmol} / \mathrm{L}$. It is not the quantitative concentration per se but the ratio of IC to EC potassium (35:I) that maintains the resting membrane potential and neuromuscular stability. Serum potassium levels are regulated closely in order to maintain neuromuscular stability. A quantitative increase in serum potassium of I mmol/L can have a significant impact on neuromuscular activity. ${ }^{2 \mathrm{I} 5}$

One source of EC potassium augmentation is glutamate. The most prominent neurotransmitter in the brain, glutamate is involved in neural plasticity and augments neuronal excitability. ${ }^{216}$ The egress of potassium from the cell changes the resting membrane potential, allowing for neurons to be more excitable.

Calcium. While potassium is the element of membrane and cell stability, calcium is the element of action, movement, and variability. Calcium is the most predominant element in the human body because of its role in skeletal formation. Of total body calcium, $99 \%$ is in bones and $\mathrm{I} \%$ is bioavailable. Of the $\mathrm{I} \%$ that is bio-available, $99.99999 \%$ is in the EC space, maintaining an EC:IC ratio of I 2 Ooo:I. Calcium reserves are extremely important to ensuring the proper adaptability of the organism during aggression and programmed changes. Approximately 50\% of serum calcium is ionized and bioavailable, and $50 \%$ is bound to proteins remaining in reserve. While cytoplasmic calcium levels are kept low, the mitochondrion and endoplasmic reticulum store calcium and make it available to calibrate cell function.

Within the blood, calcium is the essential cofactor in the coagulation cascade. Within the interstitium, it is essential as a second messenger in muscle contraction. Calcium augments the rate of neuronal signal transduction and neurotransmitter secretion through up-regulation of vesicle fusion. Within the IC space, calcium serves as a key signal transducer.

In summary, both potassium and calcium concentrations are finely regulated at the extra- and intracellular levels. Potassium is the direct IC element and maintains membrane stability. Calcium is a key element of adaptation and stimulates excitation, movement, and activity, both extra- and intracellularly. These two elements have opposing actions and overlapping factors that increase or diminish their serum concentration. Our interest in these elements with respect to the biology of functions is how they regulate or are regulated by the adaptation response.

\section{REFERENCES}

I. Elefteriou F. Regulation of bone remodeling by the central and peripheral nervous system. Arch Biochem Biophys. May I5 2008;473(2):23I-236.

2. Kim YS, Paik IY, Rhie YJ, Suh SH. Integrative physiology: defined novel metabolic roles of osteocalcin. J Korean Med Sci. Jul 2010;25(7):985-99r.

3. Lee NK, Sowa H, Hinoi E, et al. Endocrine regulation of energy metabolism by the skeleton. Cell. Aug Io 2007;130(3):456-469.

4. Palis J, Yoder MC. Yolk-sac hematopoiesis: the first blood cells of mouse and man. Exp Hematol. Aug 200I;29(8):927-936.
5. Moritz KM, Lim GB, Wintour EM. Developmental regulation of erythropoietin and erythropoiesis. Am J Physiol. Dec I997;273(6 Pt 2):RI829-I844.

6. Bleiberg I, Perah G, Feldman M. Effect of testosterone on the formation of erythroid spleen colonies from fetal liver precursor cells. Blood. Feb I973;4I(2):285-29I.

7. Congote LF. Regulation of fetal liver erythropoiesis. J Steroid Biochem. May I $977 ; 8(5): 423-428$.

8. Fisher DA. The unique endocrine milieu of the fetus. J Clin Invest. Sep I986;78(3):603-6I I.

9. Gardner FH, Pringle JC, Jr. Androgens and erythropoiesis. I. Preliminary clinical observations. Arch Intern Med. Jun I961;107:846-862.

Io. Fisher JW, Samuels AI, Malgor LA. Androgens and erythropoiesis. Isr J Med Sci. Jul-Aug I97 I;7(7):892-900.

II. Gardner FH, Gorshein D. Regulation of erythropoiesis by androgens. Trans Am Clin Climatol Assoc. 1973;84:60-70.

I2. Evens RP, Amerson AB. Androgens and erythropoiesis. J Clin Pharmacol. Feb-Mar I974;I4(2):94-IOI.

I3. ANDROGENS and erythropoiesis. Br Med J. Dec I4 I 957;2(5058):I422-I423.

I4. Alexanian R. Erythropoietin and erythropoiesis in anemic man following androgens. Blood. Apr I 969;33(4):564-572.

15. Gerbino PP. Actions of androgens on erythropoiesis. Hosp Top. Sep-Oct I974;52(8):28,55.

I6. Luque-Ramirez M, Mendieta-Azcona C, Alvarez-Blasco F, Escobar-Morreale HF. Androgen excess is associated with the increased carotid intima-media thickness observed in young women with polycystic ovary syndrome. Hum Reprod. Dec 2007;22(I2):3197-3203.

I7. Quaschning T, Ruschitzka F, Stallmach T, et al. Erythropoietin-induced excessive erythrocytosis activates the tissue endothelin system in mice. FASEB J. Feb 2003; I7 (2):259-26I.

I8. Pavlovic-Kentera V, Basara N, Jerkic M, et al. Erythrocytosis in spontaneously hypertensive rats. Exp Hematol. Dec I 988; I6(I I):950-953.

I9. Sen S, Hoffman GC, Stowe NT, Smeby RR, Bumpus FM. Erythrocytosis in spontaneously hypertensive rats. J Clin Invest. Mar I 97 2;5 I(3):7 I O-7 I 4.

20. D’Ascenzo S, Millimaggi D, Di Massimo C, et al. Detrimental effects of anabolic steroids on human endothelial cells. Toxicol Lett. Mar 8 2007;169(2):I29-136.

2I. Dickerman RD, McConathy WI, Zachariah NY. Testosterone, sex hormonebinding globulin, lipoproteins, and vascular disease risk. J Cardiovasc Risk. Oct-Dec I997;4(5-6):363-366.

22. Dickerman RD, McConathy WJ, Schaller F, Zachariah NY. Cardiovascular complications and anabolic steroids. Eur Heart J. Dec I996;I7(I2):I9I 2.

23. Winkler UH. Effects of androgens on haemostasis. Maturitas. Jul I996;24(3):I47-I 55

24. Halushka PV, Masuda A, Matsuda K. The Gordon Wilson Lecture. Regulation of thromboxane A2 receptors by testosterone: implications for steroid abuse and cardiovascular disease. Trans Am Clin Climatol Assoc. I994;I05:95-I03.

25. Noh JY, Lim KM, Bae ON, et al. Procoagulant and prothrombotic activation of human erythrocytes by phosphatidic acid. Am J Physiol Heart Circ Physiol. Aug 2010;299(2):H347-355.

26. Santos MT, Valles J, Lago A, et al. Residual platelet thromboxane A2 and prothrombotic effects of erythrocytes are important determinants of aspirin resistance in patients with vascular disease. J Thromb Haemost. Apr 2008;6(4):6 I5-62 I.

27. Valles I, Santos MT, Aznar J, et al. Erythrocyte promotion of platelet reactivity decreases the effectiveness of aspirin as an antithrombotic therapeutic modality: the effect of low-dose aspirin is less than optimal in patients with vascular disease due to prothrombotic effects of erythrocytes on platelet reactivity. Circulation. Feb 3 I 998;97(4):350-355.

28. Santos MT, Valles J, Aznar J, Marcus AJ, Broekman MJ, Safier LB. Prothrombotic effects of erythrocytes on platelet reactivity. Reduction by aspirin. Circulation. Jan 7 I997;95(I):63-68.

29. Smith MR, Lee H, Nathan DM. Insulin sensitivity during combined androgen blockade for prostate cancer. J Clin Endocrinol Metab. Apr 2006;9I(4):I305-I308

30. Lopez-Bermejo A, Diaz M, Moran E, de Zegher F, Ibanez L. A single nucleotide polymorphism in STKI I influences insulin sensitivity and metformin efficacy in hyperinsulinemic girls with androgen excess. Diabetes Care. Jul 2010;33(7):I544-I548.

3I. Smith R, Mann N, Makelainen H, Roper J, Braue A, Varigos G. A pilot study to determine the short-term effects of a low glycemic load diet on hormonal markers of acne: a nonrandomized, parallel, controlled feeding trial. Mol Nutr Food Res. Jun 2008;52(6):7 18-726.

32. English KM, Mandour O, Steeds RP, Diver MJ, Jones TH, Channer KS. Men with coronary artery disease have lower levels of androgens than men with normal coronary angiograms. Eur Heart J. Jun 2000;2 I(II):890-894

33. Jones RD, Malkin CJ, Channer KS, Jones TH. Low levels of endogenous androgens increase the risk of atherosclerosis in elderly men: further supportive data. J Clin Endocrinol Metab. Mar 2003;88(3):I403-I404; author reply $\mathrm{I} 4 \mathrm{O} 4$. 
34. Hak AE, Witteman JC, de Jong FH, Geerlings MI, Hofman A, Pols HA. Low levels of endogenous androgens increase the risk of atherosclerosis in elderly men: the Rotterdam study. J Clin Endocrinol Metab. Aug 2002;87(8):3632-3639.

35. Kupelian V, Page ST, Araujo AB, Travison TG, Bremner WJ, McKinlay JB. Low sex hormone-binding globulin, total testosterone, and symptomatic androgen deficiency are associated with development of the metabolic syndrome in nonobese men. J Clin Endocrinol Metab. Mar 2006;9I(3):843-850.

36. Hulley S, Grady D, Bush T, et al. Randomized trial of estrogen plus progestin for secondary prevention of coronary heart disease in postmenopausal women. Heart and Estrogen/progestin Replacement Study (HERS) Research Group. JAMA. Aug I9 I998;280(7):605-6I3

37. Rossouw JE, Anderson GL, Prentice RL, et al. Risks and benefits of estrogen plus progestin in healthy postmenopausal women: principal results From the Women's Health Initiative randomized controlled trial. JAMA. Jul I7 2002;288(3):32I-333.

38. Nelson HD, Humphrey LL, Nygren P, Teutsch SM, Allan JD. Postmenopausal hormone replacement therapy: scientific review. JAMA. Aug 2 I 2002;288(7):872-88I

39. Jenkins JS. The voice of the castrato. Lancet. Jun 20 I998;35 I(9 I I 9):I877-I880.

40. Paternostro G. Longevity and testosterone. Nature. Mar 3 I I994;368(6470):408.

4I. Stenholm S, Metter EJ, Roth GS, et al. Relationship between plasma ghrelin, insulin, leptin, interleukin 6, adiponectin, testosterone and longevity in the Baltimore Longitudinal Study of Aging. Aging Clin Exp Res. Apr 20II;23(2):I53-I58.

42. Toulis KA, Goulis DG, Mintziori G, et al. Meta-analysis of cardiovascular disease risk markers in women with polycystic ovary syndrome. Hum Reprod Update. Nov-Dec 20I I;I7(6):74I-760.

43. Talbott EO, Zborowskii JV, Boudraux MY. Do women with polycystic ovary syndrome have an increased risk of cardiovascular disease? Review of the evidence. Minerva Ginecol. Feb 2004;56(I):27-39.

44. Loucks TL, Talbott EO, McHugh KP, Keelan M, Berga SL, Guzick DS. Do polycystic-appearing ovaries affect the risk of cardiovascular disease among women with polycystic ovary syndrome? Fertil Steril. Sep 2000;74(3):547-552.

45. Wild S, Pierpoint T, McKeigue P, Jacobs H. Cardiovascular disease in women with polycystic ovary syndrome at long-term follow-up: a retrospective cohort study. Clin Endocrinol (Oxf). May 2000;52(5):595-600.

46. Dogramaci AC, Balci DD, Balci A, et al. Is androgenetic alopecia a risk for atherosclerosis? J Eur Acad Dermatol Venereol. Feb 232009.

47. Rasmuson S, Nasman B, Carlstrom K, Olsson T. Increased levels of adrenocortical and gonadal hormones in mild to moderate Alzheimer's disease. Dement Geriatr Cogn Disord. 2002;13(2):74-79.

48. Liu PY, Death AK, Handelsman DJ. Androgens and cardiovascular disease. Endocr Rev. Jun 2003;24(3):313-340.

49. Heinlein CA, Chang C. The roles of androgen receptors and androgen-binding proteins in nongenomic androgen actions. Mol Endocrinol. Oct 2002; I6(I0):2 I8I-2I87.

50. Michels G, Hoppe UC. Rapid actions of androgens. Front Neuroendocrinol. May 2008;29(2):I82-I98.

5I. Reisner EH, Jr. Tissue culture of bone marrow. II. Effect of steroid hormones on hematopoiesis in vitro. Blood. Apr I966;27(4):460-469.

52. Branch DW. Physiologic adaptations of pregnancy. Am J Reprod Immunol. Oct-Dec I992;28(3-4):I 2O-I 22.

53. Tanriverdi F, Silveira LF, MacColl GS, Bouloux PM. The hypothalamic-pituitary-gonadal axis: immune function and autoimmunity. J Endocrinol. Mar 2003;176(3):293-304

54. Masood DE, Roach EC, Beauregard KG, Khalil RA. Impact of sex hormone metabolism on the vascular effects of menopausal hormone therapy in cardiovascular disease. Curr Drug Metab. Oct 20I0; I I (8):693-7 I4.

55. Hammond CB, Soules M. Clinical significance of estrogen metabolism and physiology. Contemp Ob/Gyn I978; I I:4I.

56. Gore AC. Neuroendocrine targets of endocrine disruptors. Hormones (Athens). Jan-Mar 2010;9(I):I6-27.

57. Dickerson SM, Gore AC. Estrogenic environmental endocrine-disrupting chemical effects on reproductive neuroendocrine function and dysfunction across the life cycle. Rev Endocr Metab Disord. Jun 2007;8(2):I43-I59.

58. Matthews J, Gustafsson JA. Estrogen signaling: a subtle balance between ER alpha and ER beta. Mol Interv. Aug 2003;3(5):28I-292.

59. Zhao C, Dahlman-Wright K, Gustafsson JA. Estrogen receptor beta: an overview and update. Nucl Recept Signal. 2008;6:eo03.

6o. Hurvitz SA, Pietras RI. Rational management of endocrine resistance in breast cancer: a comprehensive review of estrogen receptor biology, treatment options, and future directions. Cancer. Nov I 2008; I I 3(9):2385-2397.

6I. Zhu BT, Conney AH. Functional role of estrogen metabolism in target cells: review and perspectives. Carcinogenesis. Jan I998;I9(I):I-27.

62. Pfeffer U, Fecarotta E, Vidali G. Coexpression of multiple estrogen receptor variant messenger RNAs in normal and neoplastic breast tissues and in MCF-7 cells. Cancer Res. May I5 I995;55(I0):2158-2 I65.
63. Nelson LR, Bulun SE. Estrogen production and action. J Am Acad Dermatol. Sep 200I;45(3 Suppl):SII 6-I 24 .

64. Feigelson HS, McKean-Cowdin R, Pike MC, et al. Cytochrome P45oci 7alpha gene (CYPI7) polymorphism predicts use of hormone replacement therapy. Cancer Res. Aug I5 I999;59(I6):3908-3910.

65. al-Azzawi F, Wahab M. Estrogen and colon cancer: current issues. Climacteric. Mar 2002;5(I):3-I4.

66. Crandall CJ. Estrogen replacement therapy and colon cancer: a clinical review. J Womens Health Gend Based Med. Nov I999;8(9):I I 55-I I 66.

67. Xu X, Thomas ML. Biphasic actions of estrogen on colon cancer cell growth: possible mediation by high- and low-affinity estrogen binding sites. Endocrine. Sep I995;3(9):66I-665

68. Muti P. The role of endogenous hormones in the etiology and prevention of breast cancer: the epidemiological evidence. Recent Results Cancer Res. 2005; 66 :245-256.

69. Fuster JJ, Andres V. Telomere biology and cardiovascular disease. Circ Res. Nov 24 2006;99(II):II67-II80.

70. Okuda T, Sekizawa A, Purwosunu Y, et al. Genetics of endometrial cancers. Obstet Gynecol Int. 2010;2010:984013

7I. von Dadelszen P, Watson RW, Noorwali F, et al. Maternal neutrophil apoptosis in normal pregnancy, preeclampsia, and normotensive intrauterine growth restriction. Am J Obstet Gynecol. Aug I999;I8I(2):408-4I4.

72. Nathan C. Neutrophils and immunity: challenges and opportunities. Nat Rev Immunol. Mar 2006;6(3):I73-182.

73. Park JE, Barbul A. Understanding the role of immune regulation in wound healing. Am J Surg. May 2004;187(5A): I IS-I6S.

74. Hussein OA, El-Toukhy MA, El-Rahman HS. Neutrophil CD64 expression in inflammatory autoimmune diseases: its value in distinguishing infection from disease flare. Immunol Invest. 2010;39(7):699-7 I 2.

75. Nemeth T, Futosi K, Hably C, et al. Neutrophil functions and autoimmune arthritis in the absence of prgoRhoGAP: generation and analysis of a novel null mutation in mice. J Immunol. Sep I 20I0;185(5):3064-3075.

76. Liu Z, Giudice GJ, Zhou X, et al. A major role for neutrophils in experimental bullous pemphigoid. J Clin Invest. Sep I I997;I00(5):I 256-I 263.

77. Hofman PM. Pathobiology of the neutrophil-intestinal epithelial cell interaction: role in carcinogenesis. World J Gastroenterol. Dec I4 2010;16(46):5790-5800

78. Balkwill F, Mantovani A. Inflammation and cancer: back to Virchow? Lancet. Feb I 7 200I;357(9255):539-545.

79. Allavena P, Garlanda C, Borrello MG, Sica A, Mantovani A. Pathways connecting inflammation and cancer. Curr Opin Genet Dev. Feb 2008;I8(I):3-IO.

8o. Borrello MG, Degl'Innocenti D, Pierotti MA. Inflammation and cancer: the oncogene-driven connection. Cancer Lett. Aug 28 2008;267(2):262-270.

8I. Bauer M, Eickhoff JC, Gould MN, Mundhenke C, Maass N, Friedl A. Neutrophil gelatinase-associated lipocalin (NGAL) is a predictor of poor prognosis in human primary breast cancer. Breast Cancer Res Treat. Apr 2008;108(3):389-397.

82. Fairweather D, Frisancho-Kiss S, Rose NR. Sex differences in autoimmune disease from a pathological perspective. Am J Pathol. Sep 2008;1 73(3):600-609.

83. Pietrogrande L, Raimondo E, Fossali A, Zaolino C. Biological and pharmacological factors influencing the fracture healing. Aging Clin Exp Res. Apr 20I I;23 (2 Suppl):65-68.

84. Campbell L, Emmerson E, Davies F, et al. Estrogen promotes cutaneous wound healing via estrogen receptor beta independent of its antiinflammatory activities. J Exp Med. Aug 30 2010;207(9):I825-I833.

85. Hardman MJ, Ashcroft GS. Estrogen, not intrinsic aging, is the major regulator of delayed human wound healing in the elderly. Genome Biol. 2008;9(5):R8o.

86. Mills SJ, Ashworth JJ, Gilliver SC, Hardman MJ, Ashcroft GS. The sex steroid precursor DHEA accelerates cutaneous wound healing via the estrogen receptors. J Invest Dermatol. Nov 2005;I25(5):I053-1062.

87. Ashcroft GS, Mills SJ, Lei K, et al. Estrogen modulates cutaneous wound healing by downregulating macrophage migration inhibitory factor. J Clin Invest. May 2003; I I I(9):I309-I3I8.

88. Ashcroft GS, Greenwell-Wild T, Horan MA, Wahl SM, Ferguson MW. Topical estrogen accelerates cutaneous wound healing in aged humans associated with an altered inflammatory response. Am J Pathol. Oct I 999;I55(4):I I 37 -I I 46.

89. Walker SE. Estrogen and autoimmune disease. Clin Rev Allergy Immunol. Feb 20I I; 40 (I):60-65.

9o. Ostensen M. Sex hormones and pregnancy in rheumatoid arthritis and systemic lupus erythematosus. Ann N Y Acad Sci. Jun 22 I999;876:I3I-I43; discussion I44.

9I. Crafts RG. The effects of estrogens on the bone marrow of adult female dogs. Blood. Mar I948;3(3):276-285.

92. Molloy EJ, O’Neill AJ, Grantham JJ, et al. Sex-specific alterations in neutrophil apoptosis: the role of estradiol and progesterone. Blood. Oct I 2003;102(7):2653-2659.

93. Harkonen PL, Vaananen HK. Monocyte-macrophage system as a target for estrogen and selective estrogen receptor modulators. Ann N Y Acad Sci. Nov 2006;1089:2 I 8-227. 
94. Ben-Hur H, Mor G, Insler V, et al. Menopause is associated with a significant increase in blood monocyte number and a relative decrease in the expression of estrogen receptors in human peripheral monocytes. Am J Reprod Immunol. Dec I995;34(6):363-369.

95. Ziegler-Heitbrock L. The CDi4+CDi6+ blood monocytes: their role in infection and inflammation. J Leukoc Biol. Mar 2007;8I(3):584-592.

96. Li Y, Lee PY, Reeves WH. Monocyte and macrophage abnormalities in systemic lupus erythematosus. Arch Immunol Ther Exp (Warsz). Oct 2010;58(5):355-364.

97. Sweeten TL, Posey DJ, McDougle CJ. High blood monocyte counts and neopterin levels in children with autistic disorder. Am J Psychiatry. Sep 2003;I60(9):I69I-I693.

98. Rivier A, Pene J, Rabesandratana H, Chanez P, Bousquet J, Campbell AM. Blood monocytes of untreated asthmatics exhibit some features of tissue macrophages. Clin Exp Immunol. May I995;I00(2):3I4-3I8.

99. Fingerle G, Pforte A, Passlick B, Blumenstein M, Strobel M, Ziegler-Heitbrock HW. The novel subset of CDI4+/CDI6+ blood monocytes is expanded in sepsis patients. Blood. Nov I5 I993;82(I0):3170-3176.

Ioo. Seli E, Selam B, Mor G, Kayisli UA, Pehlivan T, Arici A. Estradiol regulates monocyte chemotactic protein-I in human coronary artery smooth muscle cells: a mechanism for its antiatherogenic effect. Menopause. Jul-Aug 200I;8(4):296-30I

IоI. Hong YJ, Jeong MH, Ahn Y, et al. Relationship between peripheral monocytosis and nonrecovery of left ventricular function in patients with left ventricular dysfunction complicated with acute myocardial infarction. Circ J. Aug 2007;7 I(8):I 2 I9-I224.

I02. Beran M, Shen Y, Onida F, Wen S, Kantariian H, Estey E. Prognostic significance of monocytosis in patients with myeloproliferative disorders. Leuk Lymphoma. Mar 2006;47(3):4I7-423.

I03. Economopoulos T, Stathakis N, Maragoyannis Z, Gardikas E, Dervenoulas J. Myelodysplastic syndrome. Clinical and prognostic significance of monocyte count, degree of blastic infiltration, and ring sideroblasts. Acta Haematol. I98I;65(2):97-I02

I04. Fenaux P, Beuscart R, Lai JL, Jouet JP, Bauters F. Prognostic factors in adult chronic myelomonocytic leukemia: an analysis of I07 cases. J Clin Oncol. Sep I988;6(9):I4I 7-I424.

I05. Jaworkowsky LI, Solovey DY, Rhausova LY, Udris OY. Monocytosis as a sign of subsequent leukemia in patients with cytopenias (preleukemia). Folia Haematol Int Mag Klin Morphol Blutforsch. I983; I IO(3):395-40I.

Io6. Owen G, Lewis IJ, Morgan M, Robinson A, Stevens RF. Prognostic factors in juvenile chronic granulocytic leukaemia. Br J Cancer Suppl. Aug I992; I 8:S68-7I.

I07. Takasaki Y, Iwanaga M, Tsukasaki K, et al. Impact of visceral involvements and blood cell count abnormalities on survival in adult T-cell leukemia/ lymphoma (ATLL). Leuk Res. Jun 2007;3 I(6):75I-757.

I08. Simon JA. Safety of estrogen/androgen regimens. J Reprod Med. Mar 200I;46(3 Suppl):28I-290.

Io9. McCrohon JA, Jessup W, Handelsman DJ, Celermajer DS. Androgen exposure increases human monocyte adhesion to vascular endothelium and endothelial cell expression of vascular cell adhesion molecule-I. Circulation. May 4 I 999;99(I7):2317-2322.

I Io. Thorn GW, Forsham PH, et al. A test for adrenal cortical insufficiency; the response to pituitary andrenocorticotropic hormone. J Am Med Assoc. Jul I7 I948;I37(I2):I005-I009.

II I. Giembycz MA, Lindsay MA. Pharmacology of the eosinophil. Pharmacol Rev. Jun I 999;5I(2):2 I3-340.

I I2. Beishuizen A, Thijs LG. Relative adrenal failure in intensive care: an identifiable problem requiring treatment? Best Pract Res Clin Endocrinol Metab. Dec 200I;15(4):5I3-53I.

I I3. Beishuizen A, Vermes I, Hylkema BS, Haanen C. Relative eosinophilia and functional adrenal insufficiency in critically ill patients. Lancet. May I5 I999;353(9165): 1675 -1676.

II4. Newton R. Molecular mechanisms of glucocorticoid action: what is important? Thorax. Jul 2000;55(7):603-613.

I I5. Sabag N, Castrillon MA, Tchernitchin A. Cortisol-induced migration of eosinophil leukocytes to lymphoid organs. Experientia. May I5 I978;34(5):666-667.

II6. Ohtsu H. Progress in allergy signal research on mast cells: the role of histamine in immunological and cardiovascular disease and the transporting system of histamine in the cell. J Pharmacol Sci. Mar 2008;I06(3):347-353.

I I 7. Dimova-Yaneva D, Russell D, Main M, Brooker RJ, Helms PJ. Eosinophil activation and cysteinyl leukotriene production in infants with respiratory syncytial virus bronchiolitis. Clin Exp Allergy. Apr 2004;34(4):555-558.

I 18. Garofalo R, Dorris A, Ahlstedt S, Welliver RC. Peripheral blood eosinophil counts and eosinophil cationic protein content of respiratory secretions in bronchiolitis: relationship to severity of disease. Pediatr Allergy Immunol. May I994;5(2):I I I-II7

I I9. Kim CK, Kim SW, Kim YK, et al. Bronchoalveolar lavage eosinophil cationic protein and interleukin-8 levels in acute asthma and acute bronchiolitis. Clin Exp Allergy. May 2005;35(5):59I-597.
I 20. Kim HH, Lee MH, Lee JS. Eosinophil cationic protein and chemokines in nasopharyngeal secretions of infants with respiratory syncytial virus (RSV) bronchiolitis and non-RSV bronchiolitis. J Korean Med Sci. Feb 2007;22(I):37-42.

I2I. Phipps S, Lam CE, Mahalingam S, et al. Eosinophils contribute to innate antiviral immunity and promote clearance of respiratory syncytial virus. Blood. Sep I 2007; I IO(5):I578-I586.

I22. Priftis KN, Papadopoulou A, Liatsis E, Katsikas D, Nicolaidou P, Kanariou M. Serum eosinophil cationic protein and $\mathrm{CD}_{23}$ in acute RSV bronchiolitis. Med Sci Monit. Oct 2005; I I(IO):CR493-497.

I23. Rosenberg HF. RNase A ribonucleases and host defense: an evolving story. J Leukoc Biol. May 2008;83(5):I079-I087.

I24. Rosenberg HF, Domachowske JB. Eosinophils, ribonucleases and host defense: solving the puzzle. Immunol Res. I999;20(3):26I-274.

I 25. Rosenberg HF, Domachowske JB. Eosinophils, eosinophil ribonucleases, and their role in host defense against respiratory virus pathogens. J Leukoc Biol. Nov 200I;70(5):69I-698.

I26. Thorne KJ, Richardson BA, Veith MC, Tai PC, Spry CJ, Butterworth AE. Partial purification and biological properties of an eosinophil-activating factor. Eur J Immunol. Nov I985; I 5(I I):I083-I09I.

I27. Mingomataj EC. Eosinophil-induced prognosis improvement of solid tumors could be enabled by their vesicle-mediated barrier permeability induction. Med Hypotheses. 2008;70(3):582-584

I28. Aguilera-Aguirre L, Bacsi A, Saavedra-Molina A, Kurosky A, Sur S, Boldogh I. Mitochondrial dysfunction increases allergic airway inflammation. J Immunol. Oct I 5 2009; I83(8):5379-5387.

I29. Heidenfelder B, Johnson M, Hudgens E, et al. Increased plasma reactive oxidant levels and their relationship to blood cells, total IgE, and allergen-specific IgE levels in asthmatic children. J Asthma. Sep 2009;46(7):687-69I.

I30. Kahn JE, Dutoit-Lefevre V, Duban-Deweer S, et al. Comparative proteomic analysis of blood eosinophils reveals redox signaling modifications in patients with FIPILI-PDGFRA-associated chronic eosinophilic leukemia. J Proteome Res. Feb 8 20II.

I3I. Kuo Chou TN, Li YS, Lue KH, et al. Genetic polymorphism of manganese superoxide dismutase is associated with childhood asthma. J Asthma. Jun 2010;47(5):532-538.

I32. Lee YA, Shin MH. Mitochondrial respiration is required for activation of ERKI/2 and caspase- 3 in human eosinophils stimulated with hydrogen peroxide. J Investig Allergol Clin Immunol. 2009;I9(3):I88-I94.

I33. Tripathi P, Nair S, Singh BP, Arora N. Mutated glutathione S-transferase in combination with reduced glutathione shows a synergistic effect in ameliorating oxidative stress and airway inflammation. Free Radic Biol Med. Mar I5 20I0;48(6):839-844

I34. Jutel M, Blaser K, Akdis CA. The role of histamine in regulation of immune responses. Chem Immunol Allergy. 2006;9I:I74-I87.

I35. Jutel M, Watanabe T, Akdis M, Blaser K, Akdis CA. Immune regulation by histamine. Curr Opin Immunol. Dec 2002;I 4(6):735-740.

I36. Ochensberger B, Daepp GC, Rihs S, Dahinden CA. Human blood basophils produce interleukin- $\mathrm{I} 3$ in response to IgE-receptor-dependent and -independent activation. Blood. Oct I 5 I996;88(8):3028-3037

I37. Lantz CS, Boesiger J, Song CH, et al. Role for interleukin-3 in mast-cell and basophil development and in immunity to parasites. Nature. Mar 5 I998;392(667I):90-93

I38. Falcone FH, Haas H, Gibbs BF. The human basophil: a new appreciation of its role in immune responses. Blood. Dec I5 2000;96(I3):4028-4038.

I39. Fauci AS, Dale DC. The effect of in vivo hydrocortisone on subpopulations of human lymphocytes. J Clin Invest. Jan I974;53(I):240-246.

I40. Haynes BF, Fauci AS. The differential effect of in vivo hydrocortisone on the kinetics of subpopulations of human peripheral blood thymus-derived lymphocytes. J Clin Invest. Mar I978;6I(3):703-707.

I4I. Gatti G, Cavallo R, Sartori ML, et al. Inhibition by cortisol of human natural killer (NK) cell activity. J Steroid Biochem. Jan I987;26(I):49-58

I42. Masera R, Gatti G, Sartori ML, et al. Involvement of Ca2+-dependent pathways in the inhibition of human natural killer (NK) cell activity by cortisol. Immunopharmacology. Jul-Aug I989; I8(I):I I-22.

I43. Mendelsohn J, Multer MM, Bernheim JL. Inhibition of human lymphocyte stimulation by steroid hormones: cytokinetic mechanisms. Clin Exp Immunol. Jan I977;27(I):I 27-I34.

I44. Ansar Ahmed S, Penhale WJ, Talal N. Sex hormones, immune responses, and autoimmune diseases. Mechanisms of sex hormone action. Am J Pathol. Dec I985; I 2 I (3):53 I-55I.

I45. Gaberscek S, Zaletel K. Thyroid physiology and autoimmunity in pregnancy and after delivery. Expert Rev Clin Immunol. Sep 20I I;7(5):697-706; quiz 707.

I46. Kuijpens JL, De Hann-Meulman M, Vader HL, Pop VJ, Wiersinga WM, Drexhage HA. Cell-mediated immunity and postpartum thyroid dysfunction: a possibility for the prediction of disease? J Clin Endocrinol Metab. Jun I998;83(6): I959-I966

I47. Gerhard I, Waibel S, Daniel V, Runnebaum B. Impact of heavy metals on hormonal and immunological factors in women with repeated miscarriages. Hum Reprod Update. May-Jun I998;4(3):30I-309. 
I48. Hoermann R, Eckl W, Hoermann C, Larisch R. Complex relationship between free thyroxine and TSH in the regulation of thyroid function. Eur J Endocrinol. Jun 2010; I62(6): I I 23-I I 29.

I49. Christ-Crain M, Meier C, Huber P, Zulewski H, Staub JI, Muller B. Effect of restoration of euthyroidism on peripheral blood cells and erythropoietin in women with subclinical hypothyroidism. Hormones (Athens). Oct-Dec 2003;2(4):237-242

I50. Papic M, Stein-Streilein J, Zakarija M, McKenzie JM, Guffee J, Fletcher MA Suppression of peripheral blood natural killer cell activity by excess thyroid hormone. J Clin Invest. Feb I 987;79(2):404-408.

I5I. Bizzozero J. Ueber einen neuen Formbestandtheil des Blutes und dessen Rolle bei der Thrombose und der Blutgerinnung. Virchows Archiv. I 882;90(2):26I-332.

I52. Schmidt MB, Chen EH, Lynch SE. A review of the effects of insulin-like growth factor and platelet derived growth factor on in vivo cartilage healing and repair. Osteoarthritis Cartilage. May 2006;I4(5):403-4I2.

I53. Tennant M, McGeachie JK. Platelet-derived growth factor and its role in atherogenesis: a brief review. Aust N Z J Surg. Jul I991;6I(7):482-488.

I54. Adelson E, Rheingold JJ, Crosby WH. The platelet as a sponge: a review. Blood. Jun I96r; 7 :767-774.

I55. Gershon MD. Review article: serotonin receptors and transporters -- roles in normal and abnormal gastrointestinal motility. Aliment Pharmacol Ther. Nov 2004;20 Suppl 7:3-I4.

I56. Emiliano AB, Fudge JL. From galactorrhea to osteopenia: rethinking serotonin-prolactin interactions. Neuropsychopharmacology. May 2004;29(5):833-846.

I57. Haney EM, Chan BK, Diem SJ, et al. Association of low bone mineral density with selective serotonin reuptake inhibitor use by older men. Arch Intern Med. Jun 25 2007;I67(I2):I246-I25I.

I58. Haney EM, Warden SJ. Skeletal effects of serotonin (5-hydroxytryptamine) transporter inhibition: evidence from clinical studies. J Musculoskelet Neuronal Interact. Apr-Jun 2008;8(2):I33-I45.

I59. Weyrich AS, Zimmerman GA. Platelets: signaling cells in the immune continuum. Trends Immunol. Sep 2004;25(9):489-495.

I6o. Saxena SP, McNicol A, Brandes LJ, Becker AB, Gerrard JM. A role for intracellular histamine in collagen-induced platelet aggregation. Blood. Jan I5 I990;75(2):407-4I4.

I6I. Eckardt KU. Managing a fateful alliance: anaemia and cardiovascular outcomes. Nephrol Dial Transplant. Jun 2005;20 Suppl 6:vir6-20.

I62. Anand IS. Heart failure and anemia: mechanisms and pathophysiology. Heart Fail Rev. Dec 2008;13(4):379-386.

I63. Metivier F, Marchais SI, Guerin AP, Pannier B, London GM. Pathophysiology of anaemia: focus on the heart and blood vessels. Nephrol Dial Transplant. 2000; I5 Suppl 3:I4-I8.

I64. Glick G, Plauth WH, Jr., Braunwald E. Role of the Autonomic Nervous System in the Circulatory Response to Acutely Induced Anemia in Unanesthetized Dogs. I Clin Invest. Nov I 964;43:2 I I 2-2 I 24.

I65. Voorhess ML, Stuart MJ, Stockman JA, Oski FA. Iron deficiency anemia and increased urinary norepinephrine excretion. J Pediatr. Apr 1975;86(4):542-547.

I66. Wagner A, Fortier N, Giroux A, Lukes J, Snyder LM. Catecholamines in adult iron deficiency patients. Experientia. May I 5 I979;35(5):68I-682.

I67. Groeneveld D, Smeets HG, Kabra PM, Dallman PR. Urinary catecholamines in iron-deficient rats at rest and following surgical stress. Am J Clin Nutr. Aug I985;42(2):263-269.

I68. Hwang YC, Jeong IK, Ahn KJ, Chung HY. The uncarboxylated form of osteocalcin is associated with improved glucose tolerance and enhanced beta-cell function in middle-aged male subjects. Diabetes Metab Res Rev. Nov 2009;25(8):768-772.

I69. Im JA, Yu BP, Jeon JY, Kim SH. Relationship between osteocalcin and glucose metabolism in postmenopausal women. Clin Chim Acta. Oct 2008;396(I-2):66-69.

I70. Kindblom JM, Ohlsson C, Ljunggren O, et al. Plasma osteocalcin is inversely related to fat mass and plasma glucose in elderly Swedish men. J Bone Miner Res. May 2009;24(5):785-79I.

I7I. Munzer T, Rosen CJ, Harman SM, et al. Effects of GH and/or sex steroids on circulating IGF-I and IGFBPs in healthy, aged women and men. Am J Physiol Endocrinol Metab. May 2006;290(5):EIoo6-IoI3.

I72. Kulak CA, Baz-Hecht M, Nieves J, Shen V, Lindsay R, Cosman F. Responses of Urinary N-Telopeptide and Renal Calcium Handling to PTH Infusion after Treatment with Estrogen, Raloxifene, and Tamoxifen. Calcif Tissue Int. Feb 520 I2.

I73. Ernst M, Schmid C, Froesch ER. Enhanced osteoblast proliferation and collagen gene expression by estradiol. Proc Natl Acad Sci U S A. Apr I 988;85(7):2307-2310.

I74. DiSilvio L, Jameson J, Gamie Z, Giannoudis PV, Tsiridis E. In vitro evaluation of the direct effect of estradiol on human osteoblasts (HOB) and human mesenchymal stem cells (h-MSCs). Injury. Sep 2006;37 Suppl 3:S33-42.

I75. Baqi L, Payer J, Killinger Z, et al. Thyrotropin versus thyroid hormone in regulating bone density and turnover in premenopausal women. Endocr Regul. Apr 2010;44(2):57-63.
I76. Baqi L, Payer J, Killinger Z, et al. The level of TSH appeared favourable in maintaining bone mineral density in postmenopausal women. Endocr Regul. Jan 20I0;44(I):9-I5

I77. Guo CY, Weetman AP, Eastell R. Longitudinal changes of bone mineral density and bone turnover in postmenopausal women on thyroxine. Clin Endocrinol (Oxf). Mar I997;46(3):30I-307.

I78. Tarle M. Plasma osteocalcin values and related hormonal parameters in patients subjected to a variety of prostate anticancer agents. Urol Res. I99I;I9(I):39-44

I79. Yeung F, Law WK, Yeh CH, et al. Regulation of human osteocalcin promoter in hormone-independent human prostate cancer cells. J Biol Chem. Jan 25 2002;277(4):2468-2476

I80. Moss DW. Diagnostic aspects of alkaline phosphatase and its isoenzymes. Clin Biochem. Aug 1987;20(4):225-230.

I8I. Orimo H. The mechanism of mineralization and the role of alkaline phosphatase in health and disease. J Nippon Med Sch. Feb 20I0;77(I):4-I 2.

I82. Magnusson P, Degerblad M, Saaf M, Larsson L, Thoren M. Different responses of bone alkaline phosphatase isoforms during recombinant insulin-like growth factor-I (IGF-I) and during growth hormone therapy in adults with growth hormone deficiency. J Bone Miner Res. Feb I 997; I 2(2):2 I0-220.

I83. Stepan J, Havranek T, Formankova J, Skrha J, Skrha F, Pacovsky V. Bone isoenzyme of serum alkaline phosphatase in diabetes mellitus. Clin Chim Acta. Jul I7 I980;I05(I):75-8I.

I84. Aliev M, Guzun R, Karu-Varikmaa M, Kaambre T, Wallimann T, Saks V. Molecular System Bioenergics of the Heart: Experimental Studies of Metabolic Compartmentation and Energy Fluxes versus Computer Modeling. Int J Mol Sci. 20I I; I 2(I 2):9296-933I.

I85. Wallimann T, Hemmer W. Creatine kinase in non-muscle tissues and cells. Mol Cell Biochem. Apr-May I994;I33-I34:193-220.

I86. Brancaccio P, Lippi G, Maffulli N. Biochemical markers of muscular damage. Clin Chem Lab Med. Jun 2010;48(6):757-767.

I87. Banfi G, Colombini A, Lombardi G, Lubkowska A. Metabolic markers in sports medicine. Adv Clin Chem. 20I 2;56:I-54.

I88. Bagley WH, Yang H, Shah KH. Rhabdomyolysis. Intern Emerg Med. Oct 2007;2(3):210-218.

I89. Newsholme EA, Beis I, Leech AR, Zammit VA. The role of creatine kinase and arginine kinase in muscle. Biochem J. Jun I5 I978;172(3):533-537.

I9o. Khan HA, Alhomida AS, Sobki SH, Moghairi AA, Koronki HE. Blood cell counts and their correlation with creatine kinase and C-reactive protein in patients with acute myocardial infarction. Int J Clin Exp Med. 20I2;5(I):50-55.

I9I. Karras DJ, Kane DL. Serum markers in the emergency department diagnosis of acute myocardial infarction. Emerg Med Clin North Am. May 200I;I9(2):32 I-337.

I92. Green SM, Vowels J, Waterman B, Rothrock SG, Kuniyoshi G. Leukocytosis: a new look at an old marker for acute myocardial infarction. Acad Emerg Med. Nov I996;3(II):I034-IO4I.

I93. Paul GK, Sen B, Bari MA, et al. Correlation of platelet count and acute ST-elevation in myocardial infarction. Mymensingh Med J. Jul 20I0;I9(3):469-473.

I94. Vermeulen RC, Kurk RM, Visser FC, Sluiter W, Scholte HR. Patients with chronic fatigue syndrome performed worse than controls in a controlled repeated exercise study despite a normal oxidative phosphorylation capacity. J Transl Med. 2010;8:93

I95. Diaz-Olmos R, Nogueira AC, Penalva DQ, Lotufo PA, Bensenor IM. Frequency of subclinical thyroid dysfunction and risk factors for cardiovascular disease among women at a workplace. Sao Paulo Med J. Jan 20I0;I 28(I): I 8-23.

I96. Haentjens P, Van Meerhaeghe A, Poppe K, Velkeniers B. Subclinical thyroid dysfunction and mortality: an estimate of relative and absolute excess allcause mortality based on time-to-event data from cohort studies. Eur J Endocrinol. Sep 2008;159(3):329-34I.

I97. Rodondi N, Bauer DC, Cappola AR, et al. Subclinical thyroid dysfunction, cardiac function, and the risk of heart failure. The Cardiovascular Health study. J Am Coll Cardiol. Sep 30 2008;52(I4):I I52-II59.

I98. Burnett JR, Crooke MJ, Delahunt JW, Feek CM. Serum enzymes in hypothyroidism. N Z Med J. Sep I4 I994;I07(985):355-356.

I99. Saha B, Maity C. Alteration of serum enzymes in primary hypothyroidism. Clin Chem Lab Med. Jun 2002;40(6):609-6I I.

200. Hekimsoy Z, Oktem IK. Serum creatine kinase levels in overt and subclinical hypothyroidism. Endocr Res. 2005;3 I(3):I 7 I-I 75

20I. Beyer IW, Karmali R, Demeester-Mirkine N, Cogan E, Fuss MJ. Serum creatine kinase levels in overt and subclinical hypothyroidism. Thyroid. Nov I998;8(II):I029-I03I.

202. Chazov EI, Smirnov VN, Zisko AP, Stark VM. Serum lactic dehydrogenase isoenzyme patterns in coronary atherosclerosis. J Atheroscler Res. Mar-Apr I969;9(2):203-207.

203. Karacalioglu O, Arslan Z, Kilic S, Ozturk E, Ozguven M. Baseline serum levels of cardiac biomarkers in patients with stable coronary artery disease. Biomarkers. Sep-Oct 2007; I2(5):533-540.

204. Feron O. Pyruvate into lactate and back: from the Warburg effect to symbiotic energy fuel exchange in cancer cells. Radiother Oncol. Sep 2009;92(3):329-333. 
205. Kato GJ, McGowan V, Machado RF, et al. Lactate dehydrogenase as a biomarker of hemolysis-associated nitric oxide resistance, priapism, leg ulceration, pulmonary hypertension, and death in patients with sickle cell disease. Blood. Mar I5 2006; IO7(6):2279-2285.

206. Mansuroglu D, Omeroglu SN, Izgi A, et al. LDH levels and left atrial ultrastructural chances in patients with mitral paraprosthetic regurgitation. J Card Surg. May-Jun 2005;20(3):229-233.

207. Bien E, Balcerska A. [Clinical significance of erythrocyte sedimentation rate, C-reactive protein and serum lactate dehydrogenase levels in the diagnosis, prognosis and treatment monitoring of children suffering from cancer]. Med Wieku Rozwoj. Oct-Dec 2004;8(4 Pt 2):I08I-I089.

208. Pui CH, Dodge RK, Dahl GV, et al. Serum lactic dehydrogenase level has prognostic value in childhood acute lymphoblastic leukemia. Blood. Oct I985;66(4):778-782.

209. Draoui N, Feron O. Lactate shuttles at a glance: from physiological paradigms to anti-cancer treatments. Dis Model Mech. Nov 2010;4(6):727-732.

2 Io. Dutton CM, Joba W, Spitzweg C, Heufelder AE, Bahn RS. Thyrotropin receptor expression in adrenal, kidney, and thymus. Thyroid. Dec I997;7(6):879-884.

2I I. Robbins RJ, Leidy JW, Jr., Landon RM. The effects of growth hormone, prolactin, corticotropin, and thyrotropin on the production and secretion of somatostatin by hypothalamic cells in vitro. Endocrinology. Aug I985; II 7(2):538-543.

2I2. Banu KS, Aruldhas MM. Sex steroids regulate TSH-induced thyroid growth during sexual maturation in Wistar rats. Exp Clin Endocrinol Diabetes. Jan 2002;IIO(I):37-42.

2I3. Morley JE. Extrahypothalamic thyrotropin releasing hormone (TRH) - its distribution and its functions. Life Sci. Oct 29 I979;25(I8):I539-I550.

2I4. Mortimer CH, Besser GM, McNeilly AS, Tunbridge WM, Gomez-Pan A, Hall R. Interaction between secretion of the gonadotrophins, prolactin, growth hormone, thyrotrophin and corticosteroids in man: the effects of LH FSH-RH, TRH and hypoglycaemia alone and in combination. Clin Endocrinol (Oxf). Oct I973;2(4):317-326.

2I5. Singer GG, Brenner BM. Fluid and electrolyte disturbances. In: Kasper DL, Harrison TR, eds. Harrison's principles of internal medicine. I6th ed. New York: McGraw-Hill, Medical Pub. Division; 2005:2 v. (xxvii, 2607, [26I5, 2I 28] p.).

2I6. Durand D, Pampillo M, Caruso C, Lasaga M. Role of metabotropic glutamate receptors in the control of neuroendocrine function. Neuropharmacology. Sep 2008;55(4):577-583. 